Ittishal Educational Research Journal January 2021, Vol. 2, No. 01, p. 43 - 58 http://journal.ittishal.net/index.php/ierj

DOI 10.51425/ierj.v2i1.11

\title{
The Influence Fear of Missing Out against Social Media Addiction In Early Teens
}

\author{
Ester Ana \\ Universitas Mercubuana Yogyakarta, Indonesia \\ Esterana89@yahoo.com
}

\begin{abstract}
This study aims to determine the influence is between fear of missing out (FoMO) and addiction to social media in early teens. This study involved one dependent variable, social media addiction, and one independent variable that influenced it, fear of missing out (FoMO). There were 152 participants in this study. The participants of this study were adolescents aged 12-15 years who have social media such as Instagram, Facebook, and Twitter. The research method used the Likert scale and data analysis using the product-moment correlation, the result was $\mathrm{r}=$ 0.593. The higher the fear of missing out, the higher the addiction to social media, and vice versa. The contribution between fear of missing out (FoMO) and addiction to social media in early adolescents was 0.351 or $35.1 \%$ explained by the fear of missing out (FoMO) variable, while the remaining $64.9 \%$ was explained by other variables.
\end{abstract}

Keywords: fear of missing out; social media addiction; early teens 


\section{INTRODUCTION}

According to research by social media management platform Hoot Suite and social marketing agency, We Are Social titled "Global Digital Reports 2020", almost 64 percent of Indonesians are connected to the internet. The research released at the end of January 2020 stated that the number of internet users in Indonesia has reached 175.4 million people, while the total population of Indonesia is around 272.1 million. Compared to 2019, the number of internet users in Indonesia increased by about 17 percent, or 25 million users (Kemp, 2020).

The world is currently facing the COVID-19 pandemic. Severe acute respiratory syndrome corona virus 2 (SARS-CoV-2) infection, which clinically manifests primarily in this respiratory system (COVID-19), has a high enough rate of transmission in various parts of the world that WHO finally establishes pandemic status for this infectious disease. This has even encouraged some countries to implement lock down policies to prevent the spread of this virus widely and massively (Ministry of Health of the Republic of Indonesia, 2020).

In response, the Indonesian government began to implement large-scale social restrictions (PSBB) for several regions, one of the strategies was physical distancing. With the implementation of physical distancing, especially teenagers who are mostly studying, doing most of their activities from home. The implementation of the policy, especially for teenagers who sit in school and college, has the potential to increase internet use in everyday life. The potential for the use of the internet and how to use the internet wisely and healthily needs to be recognized, not only by teenagers but also by education practitioners and policymakers (Muhammad Thoriq et al., 2020).

In the education sector, it has made teenagers who are taking the education level off from face-to-face activities in schools/campuses and replacing it with internet-based distance learning methods (Ministry of Health, Republic of Indonesia, 2020). By utilizing the capabilities of the internet, this method is not only able to facilitate the delivery of learning materials, but can also be used to evaluate the reach of learners' learning goals. Long-term internet usage will continuously have an impact on its users, both positive and negative impacts in the future 
(Nugraha, 2013). If not managed wisely, these learning methods can position teenagers to always use the internet most of their daily life.

Social media is the most accessed site by its users because it has many advantages. These advantages include as a medium of information and communication, establishing relationships, as a forum to present themselves to their users, as well as facilitate individuals in the world of business, career, education, and politics. In addition, the positive impacts caused by the internet include facilitating correspondence, sending messages, chatting, taking or sending information, and means for entertainment (Fauziawati, 2015). In addition to having the advantage, social media has disadvantages or negative things. These negatives include spending a lot of time accessing social media, individuals becoming unproductive, and tending to be lazy personal. Generally, teenagers are not able to filter good or bad things from the internet, so teenagers are vulnerable to negative impacts from their use.

These impacts are experienced by adolescents, especially early adolescents because they are a vulnerable population. Early teens become more vulnerable because their emotional control state is still developing so that the regulatory capacity that teenagers have can not be fully used to control the use of social media (Berthelsen, Hayes, White \& William, 2017). The results of research conducted by Listari (2018) that 245 teenagers, early teens aged 13-15 years became the most dominant teenagers using social media and 183 of them used excessive social media for more than two hours. Increased adolescent time in intensive and even excessive use of social media increases the risk of developing dependency and social media behavior (Tzavela, 2015).

Online social networking site addiction or known as social media addiction is an act where the individual pays attention to social media and devotes a lot of time and effort to social media thus disrupting other social activities, studies/work, interpersonal relationships, and psychological health and well-being (Griffiths, 2017). The presence of social media makes it easy for people to access anything and anywhere and makes it easier to make ends meet. The main function of social media is to make it easier for people to communicate indefinitely space and time, 
providing information from any part of the world. Social media that is growing and loved by teenagers today are Facebook, WhatsApp, Instagram (Wahyuni, 2018). According to Young (2010), internet addiction is defined as a syndrome characterized by spending a very large amount of time using the internet and not being able to control its use while online

Internet use is increasing due to the tendency of individuals to obtain the latest information. It also causes discomfort and anxiety in a person if they cannot access the internet. According to Dossey (2014), the feeling of anxiety for fear of feeling left behind is called fear of missing out (FoMO). Fear of missing out (FoMO) is referred to as social anxiety born from the advancement of technology, information, and the increasing existence of social media.

Neuroticism correlates positively with social networking sites. Neuroticism is known in the form of the tendency to experience unpleasant emotions (anxiety, depression, fear) associated with the tendency to addicted to social networking sites (Andreassen, 2016). FoMO is defined as a pervasive form of fear experienced when not involved in a moment of events, experiences, or discussions that are taking place in the social environment, which is characterized by a desire to stay connected to the activities that others are doing (Przybylski, 2013). In addition, FoMO is also described as a feeling of anxiety that arises when left behind an interesting event experience that is being experienced by a friend, when a friend knows more interesting information, or when a friend has something better.

FoMO can affect the tendency of internet addiction due to unmet psychological needs of relatedness and self are important aspects in FoMO, which influences individuals to continue to use the internet so that the individual feels fulfilled psychological needs. The ease of accessing various information over the internet can encourage individuals to more easily compare their lives to the lives of others that the individual reads and sees from what others show on the internet (Abel, 2016). 


\section{LITERATURE REVIEW}

The term social media is composed of two words, namely media and social. Media is defined as a means of communication (Laughey, 2007; McQuail, 2003). While the word social is defined as the social reality that each individual performs actions that contribute to society. This statement asserts that in fact, the media and all software constitute social or in the meaning that both are products of social processes (Durkheim in Fuchs, 2014).

Social media is a virtual community forum where users can create individual public profiles, interact with friends in the real world and meet others based on mutual interests (Griffiths, Pallesen, \& D, 2017). Social media has the same function as social interaction in general which is to create and maintain relationships and to present themselves and identity. Social media is a means for consumers to share text, image, video, and audio information and with companies and vice versa (Jan H. Kietzmann, 2010).

Social media addiction based on the concept of addiction in general is excessive and uncontrolled activities accompanied by a desire to stay connected with social media so that individuals devote so much time and effort and interfere with other important aspects of life (Andreassen, 2016). Excessive use of social media is equivalent to a condition of compulsive behavior or inability to prevent one's self from committing a desire because if the desire is not done it will cause anxiety or aggressive behavior in this case towards the use of social media (Ama, 2008).

Social media usage behavior has become a habit of individual daily life, checking social media many times every hour and feeling lost if in a day does not open social media as a result users can engage with social media more often and will have a tendency to social media addiction (Salehan, 2013). duration of teenagers who use social media for two hours or more in a day can be said to be excessive social media users and have a tendency to social media addiction (Tsitsika, 2014).

Griffiths (2005) mentions also the 'component model', which defines addiction as the relationships numbers of meaning / prominence (salience), mood modification (mood modification), tolerance (tolerance), withdrawal 
(withdrawal), conflict (conflict), and repeat / relapse ( relapse). These components reflect the biological and psycho-social features of the phenomenon of addiction, and everything must be there to consider any behavior as an addiction. A form of behavior that meets these six criteria, the use of social media is defined as an addiction (Griffiths, Pallesen, \& D, 2017).

LaRose (2011) explains that individuals who experience social media addiction begin with a high need to use social media. Whiting and Williams (2013) presented ten factors underlying individuals using social media based on theories of use and gratifications. FoMO is the constant anxiety of being left behind or losing something valuable, individuals with FoMO will not know the specifics of what is missing but will feel the loss of others has a precious moment (Intelligence, 2012).

FoMO is the fear of losing a precious moment of another individual or group where the individual is unable to be present in it and is characterized by a desire to stay connected to what others are doing through the internet or cyberspace (Przybylski, 2013). FoMO is a situational state when psychological needs are not met in self and relatedness

\section{METHOD}

Participants in this study were teenagers aged between 12 - 15 years. The consideration of selecting teenagers of that age to be participants is based on Hayes, White, and William (2017) that early adolescents become vulnerable populations in the use of social media. The population in this study was teenagers aged 12-15 years, total 270 participants. They are students in one of the schools in Yogyakarta. The criteria of the subject are teenagers aged 12-15 years, have social media accounts (i.e. Instagram, Twitter, and Facebook).

The sampling technique in this research is the probability sampling technique which is a sampling technique that provides equal opportunity for each element (member) of the population to be selected as a sample member (Sugiyono, 2014). If the youth population is 270 people with a significance of $5 \%$, then it can be seen from the table Nomogram Harry King (Sugiono, 2014), which shows that the sample was taken, 152 people. 
The research methodology is the quantitative approach using the scale method. The measurement scale in this study was compiled according to the Likert scale model consisting of several statements of favorable and unfavorable attitudes. Data analysis used is product-moment correlation analysis and coefficient of determination, to facilitate data analysis calculation, researchers use SPSS program assistance.

\section{FINDINGS AND DISCUSSION}

Based on the results of the hypothesis trial, obtained product-moment correlation value between fear of missing out (FoMO) variable and social media addiction is 0.593 with $p$ is 0.000 means p\&lt value; 0.01 . Based on the productmoment correlation test, the hypothesis that researchers submitted in this study accepted, that there is a positive relationship between fear of missing out and social media addiction That is, the higher the fear of missing out than the higher the social media addiction and vice versa, the lower the fear of missing out than the lower the social media addiction.

Table 1

Product Moment Correlation Analysis Results

\begin{tabular}{|c|c|c|c|c|}
\hline $\begin{array}{l}\text { Independent } \\
\text { Variables }\end{array}$ & $\begin{array}{l}\text { Dependent } \\
\text { Variables }\end{array}$ & & & Description \\
\hline & & $\begin{array}{l}\text { Correlation } \\
\text { Value }\end{array}$ & Sig & \\
\hline $\begin{array}{l}\text { Fear of Missing } \\
\text { Out (FoMO) }\end{array}$ & $\begin{array}{l}\text { Social } \\
\text { Media } \\
\text { Addiction }\end{array}$ & 0,593 & 0,000 & Significant \\
\hline
\end{tabular}

LaRose (2011) explains that individuals who experience social media addiction begin with a high need to use social media. Social media addiction based on the concept of addiction in general is excessive and uncontrolled activities accompanied by a desire to stay connected with social media so that individuals devote so much time and effort and interfere with other important aspects of life (Andreassen, 2016). 
Whiting and Williams (2013) presented ten factors underlying individuals using social media based on the theory of uses and gratifications, one of the factors that influenced it was FoMO. Defined as the use of social media aims to find out information about others or keep an eye on something others are doing. Social media can be used to find out what others are doing and even keep an eye on others on social media. If someone finds out information about someone else or is compulsively watching others on social media it can be said that someone is experiencing FoMO because they are worried about not connecting with the activities others are doing (Przybylski, 2013).

Przybylski (2013) mentions aspects of FoMO, namely situation circumstances when psychological needs are not met in relatedness and self. Relatedness (closeness or desire to connect with others) is the need for a person to feel a feeling of being joined, connected, and together with others. Conditions such as strong, warm, and can satisfy the need for connection so that individuals feel like they want to have more opportunities to interact with people who are considered important and continue to develop their social competencies. If the psychological need for relatedness is not met it causes the individual to feel anxious and try to find out the experience and what others are doing, one of which is through the internet.

The psychological need for self (self) is related to competence and autonomy. Competence is defined as an inherent desire for individuals to feel effective in interacting with their environment reflecting the need to train abilities and seek optimal challenges (Reeve \& Sickenius in Tekeng, 2015). This competence needs to be related to the individual's belief to perform certain actions or behaviors efficiently and effectively. Autonomy is the experience of sensing the choice, support, and willingness associated with initiating, nurturing, and ending behavioral engagement (Niemic, Lynch, Vansteenkistec, Bernstein, Deci \& Ryan in Tekeng, 2015). Autonomy means that an individual is free to integrate self-executed actions without being bound or gaining control from others (the individual is the initiator and source of his behavior). If the psychological need for self is not met, then the individual will channel it through the internet to obtain a variety of information and connect with others. 
The needs and encouragement that arise from FoMO in maintaining communication can be met through social media. The availability of information from social media allows individuals to know what events others are doing all the time. This causes individuals experiencing FoMO to lead to social media addiction (Abel, 2016).

The results of this study reinforce research conducted by Blackwell et al (2017) found that fear of missing out significantly affects social media addiction. In line with the results of research conducted by Hariadi (2018) which also found that fear of missing out affects social media addiction in teenagers in MAN Surabaya significantly.

Based on the results of the determinant coefficient test for per variable, variable FoMO contribution to social media addiction was $35.1 \%$. This means that FoMO contributes to social media addiction by $35.1 \%$ and the rest is influenced by other variables.

The coefficient of determination (effective donation) of FoMO to predict social media addiction can be seen from $\mathrm{R}$ square (R2)which appears in the following table:

Result of Coefficient of Determination

\begin{tabular}{lllll}
\hline Model & $\mathbf{R}$ & R Square & $\begin{array}{l}\text { Adjusted } \\
\text { Square }\end{array}$ & $\begin{array}{l}\text { Std. Error of } \\
\text { the } \\
\text { Estimate }\end{array}$ \\
\hline $\mathbf{1}$ & 0,593 & 0,351 & 0,347 & 12,653 \\
\hline
\end{tabular}

Based on the table above, the variable determination coefficient test that occurred in social media addiction variable in early adolescence seen in R Square column of 0.351 or $35.1 \%$ was explained by FoMO variable while the remaining $64.9 \%$ was influenced by other factors not studied in this study. 


\section{CONCLUSION}

Based on the above exposure, it can be concluded that there is a positive relationship between FoMO and social media addiction in early teens. The higher of FoMO, they tend to be higher social media addiction in early adolescence and vice versa. This is evident from the results of product-moment correlation analysis that showed a strong correlation between fear of missing out and social media addiction of 0.593 . The positive relationships that occurred from the two variables also showed that the existence of a significant relationship, the FoMO led to high social media addiction behavior. The results showed a variable fear of missing out on social media addiction by $35.1 \%$. 


\section{REFERENCES}

Abel, J. P. (2016). Social media and fear of missing out: scale development and assessment. Journal of Business \& Economics Research, 33-43.

Agustiani, H. (2006). Psikologi Perkembangan Pendekatan Ekologi Kaitannya Dengan Konsep Diri Dan Penyesuaian Diri Pada Remaja. Bandung: PT. Refika Aditama.

Aliffatullah Alyu Raj, S. N. (2017). Dampak Kecanduan Internet (Internet Addiction) Pada Remaja. Prosiding Temu Ilmiah X Ikatan Psikologi Perkembangan Indonesia.

Al-Menayes, J. (2016). "The Fear of Missing Outscale: Validation of the Arabic Version and Correlation with Media Social Addiction". International Journal of Applied Psychology, 41-46.

Alt, D. (2015). “College Students' Academic Motivation, Media Engagement And Fear Of Missing Out". Computers In Human Behavior, 111-119.

Andreassen, C. S. (2016). "Psychology Of Addictive Behaviors. The Relationship Between Addictive Use Of Social Media And Video Games And Symptoms Of Psychiatric Disorders", 252-262.

Arnett, J. J. (2013). Adolescence and Emerging Adulthood: A Cultural Approach. Upper Saddle River.

Association, AMA. (2008). "Emotional and Behavioral Effects of Video Games and Internet Overuse (A-07)". USA: Psychological Testing.

Baron, R. d. (2005). Psikologi sosial. Edisi kesepuluh: jilid 2. Jakarta: Erlangga.

Beyens, I. F. (2016). “I Don't Want To Miss A Thing: Adolescents' Fear Of Missing Out And Its Relationship To Adolescents' Social Needs, Facebook Use, And Facebook Related Stress". Computers in Human Behavior, 1-8.

Blachino, A. (2017). “Facebook Intrusion, Fear Of Missing Out, Narcissism, And Life Satisfaction: A Cross-Sectional Study". Psychiatry Research.

Chaplin, J. (2004). Kamus Lengkap Psikologi, Penerjemah : Kartini Kartono. Cetakan Kelima. Jakarta: PT. Rejo Grafindo Persada.

Chen, Y. C. (2005). “An Analysis Of Online Gaming Crime Characteristics. Internet Research", 246 - 261. 
Chou, H. T. (2012). "They Are Happier And Having Better Lives Than I Am": The Impact Of Using Facebook On Perceptions Of Others' Lives". Cyberpsychology, Behavior, and Social Networking, 117-121.

Cialdini, R. B. (2004). "Social Influence: Compliance And Conformity". Annual Review of Psychology, 591-621.

Dina, S. (2017). Membangun Kepekaan Bersosial Media pada Generasi Muda. Dipetik Oktober 4, 2019, dari Kominfo: https://www.kominfo.go.id/content/detail/11997/membangun-kepekaanbersosial-media-pada-generasi-muda/0/sorotan_media

Dossey, L. (2014). “FOMO, Digital Dementia And Our Dangerous Experiment. Exploration".

Gezgin, D. M. (2016). “Analysis of Nomofobic Behaviors of Adolescents Regarding Various Factors". Journal of Human Sciences, 2504-2519. oi:10.14687/jhs.v13i2.3797

Griffiths, A. C., Pallesen, S., \& D, M. (2017). “ The relationship between addictive use of social media, narcissism, and self-esteem: Findings from a large national survey". Addictive Behaviour, 287-293.

Hurlock, E. B. (2009). Psikologi Perkembangan: Suatu Pendekatan Sepanjang Rentang kehidupan. Jakarta: Erlangga.

Indonesia, D. P. (2008). Kamus Besar Bahasa Indonesia. Jakarta: Balai Pustaka.

Intelligence, J. (2012). Fear of Missing Out (FOMO). Retrieved from www.jwtintelligence.com/wp-content/uploads/2012/03/F_JWT_ FOMOupdate_3.21.12.pdf, March 5, 2020,

Jan H. Kietzmann, K. H. (2010). "Social Media? Get Serious! Understanding The Functional Building Blocks Of Social Media". Slovenia. Business Horizons 86, $241-251$.

Jannah, N. M. (2015). Hubungan Kecanduan Game dengan Motivasi Belajar Siswa dan Implikasinya Terhadap Bimbingan dan Konseling. Universitas Negeri Padang, 200-207.

Karpinski, A. K. (2010). “Facebook and Academic Performance”. Journal Computer in Human Behavior, 1237- 1245. 
Kemp, S. (2020). "Digital 2020: 3.8 Billion People Use Social Media". Dipetik February 2, 2020, dari we are social: https:// wearesocial.com/blog/2020/01/digital-2020-3-8-billion-people-usesocial-media

Kominfo. (2017). Survey Penggunaan TIK . Kementerian Komunikasi dan Informatika Republik Indonesia, Badan Penelitian dan Pengembangan Sumber Daya Manusia. Jakarta: Pusat Penelitian dan Pengembangan Aplikasi Informatika dan Informasi dan Komunikasi Publik. Dipetik Maret 9, 2020, dari https:/ / balitbangsdm.kominfo.go.id/?mod=publikasi\&a=dl\&page_id=360\& cid=9\&download_id $=187$

Kowalski, R. M. (2013). "Psychological, Physical, And Academic Correlates Of Cyberbullying And Traditional Bullying". Journal of Adolescent Health, S13S20.

Kurniasanti, K. S (2019)." Internet Addiction: A New Addiction?", Medical Journal Ofindonesia, 28(1), Pp. 82-91.

Kuss, D. J. (2011). “Online Social Networking And Addiction - A Review Of The Psychological Literature". International Journal of Environmental Research and Public Health, 3528-3552.

L., C. (2013,). "Fomo And Mobile Phones: A Survey Study" arno: www.arno.uvt.nl/show.cgi?fid=130776

Ma'rifatul Laili, F. (2005). Penerapan Konseling Keluarga Untuk Mengurangi Kecanduan Game Online Pada Siswa Kelas Viii Smp Negeri 21 Surabaya. Jurnal BK, 65-72.

Margono. (2004). Metodologi Penelitian Pendidikan. Jakarta: Rineka Cipta.

Masya, H. (2016). Faktor-Faktor yang Mempengaruhi Perilaku Gangguan Kecanduan Game Online pada Peserta Didik Kelas X di Madrasah Aliyah Al Furqon Prabumulih Tahun Ajaran 2015/2016. Jurnal Bimbingan dan Konseling, 3.

Mawardah, U. (2012). “Relationship Between Active Coping With Parenting Stress In Mother Of Mentally Retarded Child". Jurnal Psikologi, 1, 1-1. 
Monks, F. K. (2004). Psikologi Perkembangan. Yogyakarta: Gadjah Mada University Press.

Montag, C. \&. (2015). Molecular Genetics, Personality, and Internet Addiction. In C. Montag \& M. Reuter (Eds.), Internet addiction, studies in neuroscience, psychology and behavioral economics, 93-109.

Mulyani, I. M. (2018). Perilaku adiksi pada Instagram di kalangan remaja. Psikologi Universitas Gadjah Mada.

Myers, D. G. (2012). Psikologi Sosial Jilid 2. Jakarta: Salemba Humanika.

Nurihsan, A. d. (2013). Dinamika Perkembangan Anak \& Remaja. Bandung: Refika Aditama.

Nugraha, S. A. \& H. D. (2013).Perkembangan Media Informasi Dan Teknologi. Perkembangan Media Informasi dan Teknologi Terhadap Anak dalam Era Globalisasi.

O'Keeffe, G. S. (2011). “ The Impact Of Social Media On Children, Adolescents, And Families". Journal The American Acadey Of Pediatrics, 127, 800-804.

Ozkan, M. (2015). “Mobile Addiction Of Generation $Z$ And Its Effects On Their Social Lifes". Procedia - Social and Behavioral Sciences, 92-98.

Papalia, E. D. (2014). Menyelami Perkembangan Manusia ; Experience Hman Development. Jakarta: Salemba Humanika.

Przybylski, A. K. (2013). Motivational, Emotional, And Behavioral Correlates Of Fear Of Missing Out. Computer in Human Behavior, 1841-1848.

Reagle, J. (2015). "Following The Joneses: FOMO And Conspicuous Sociality". First Monday, 1-8.

Rini, A. (2011). Menanggulangi Kecanduan Game On-Line Pada Anak. Jakarta. Pustaka Mina.

Rosenberg KP, Feder LC. (2014). “Behavioral Addictions: Criteria, Evidence, And Treatment". London: Elsevier academic press

Saifuddin, A. (2013). Metode Penelitian . Yogyakarta: Pustaka Pelajar.

Salehan, M. \&. (2013). "Social Networking On Smartphones: When Mobile Phones Become Addictive". Computers in Human Behavior, 2632-2639. 
Santoso, T. W. (2016). Perilaku Kecanduan Permainan Internet Dan Faktor Penyebabnya Pada Siswa Kelas VIII Di SMP Negeri 1 Jatisrono Kabupaten Wonogiri. Studi Kasus pada Siswa Kelas VIII Di SMP 1 Jatisrono Kabupaten Wonogiri.

Santrock, J. (2012). Life-Span Development (Perkembangan Masa Hidup Edisi 13 Jilid 1. Jakarta: Erlangga.

Schrock, A. (2006). “Myspace Or Our space: A Media System Dependency View Of Myspace". The University Of Central Florida.

Sianipar, N. A. (2019). Hubungan Antara Regulasi Diri dengan Fear of Missing Out (FoMO) Pada Mahasiswa Tahun Pertama Fakultas Psikologi Universitas Diponegoro. Jurnal Empati, 136-143.

Soeparno, K. \&. (2011). "Social Psychology: The Passion Of Psychology". Buletin Psikologi Fakultas Psikologi Universitas Gadjah Mada.

Soliha, S. F. (2015). Tingkat ketergantungan pengguna media sosial dan kecemasan sosial. Jurnal Interaksi, 1-10.

Stead, H. \&. (2017). "Personality, fear of missing out and problematic internet use and their relationship to subjective well-being". Computers in Human Behavior, 534-540.

Subathra, N. d. (2013). “A Study On The Level Of Social Network Addiction Among College Students". Social Science, 3, 355- 357.

Sugiyono. (2014). Metode Penelitian Pendidikan Pendekatan Kuantitatif, Kualitatif, dan R\&D,. Bandung: Alvabeta.

Taylor, S. E. (2009). Psikologi Sosial Edisi Kedua Belas. Jakarta: Kencana Prenada Media Group.

Tekeng, S. N. (2015). Peranan kepuasan kebutuhan dasar psikologis dan orientasi tujuan mastery approach terhadap belajar berdasar regulasi diri mahasiswa. Yogyakarta: Fakultas Psikologi Universitas Gadjah Mada.

Tomczyk, L. \&.-L. (2018). “Fear Of Missing Out (Fomo) Among Youth In Bosnia And Herzegovina - Scale And Selected Mechanisms." Children and Youth Service Review. 
Tsitsika, A. J. (2014). "Internet Addictive Behavior In Adolescence: A CrossSectional Study In Seven European Countries". Cyberpsychology, Behavior and Social Networking, 28-535

Tzavela, E. C. (2015). Processes Discriminating Adaptive And Maladaptive Internet Use Among European Adolescents Highly Engaged Online. Journal of Adolescents, 36-47.

Tzavela, E. C. (2015). Processes Discriminating Adaptive And Maladaptive Internet Use Among European Adolescents Highly Engaged Online. Journal of Adolescents, 36-37.

Wang, C. L. (2014). "A Theory Of Social Media Dependence: Evidence From Microblog Users". Decision support system, 40-49. doi:10.1016/j.dss.2014.11.00

Wortham, J. (2011). "Feel Like A Wallflower? Maybe It's Your Facebook Wall." Diambil kembali dari NYtimes: http:/ / www.nytimes.com/2011/04/10/business/10ping.html

Young, K. S. (2011). "Prevalence Estimates And Etiologic Models Of Internet Addiction". INTERNET ADDICTION: A Handbook And Guide To Evaluation And Treatment, 3-18.

Yusuf, S. (2006). Psikologi Perkembangan Anak dan Remaja. Bandung: PT. Remaja Rosdakarya. 